\title{
Studi Model Bisnis Coworking Space Di Kota Pekanbaru
}

\author{
MUTIA ULFAH \\ Dosen Tetap Sekolah Tinggi Ilmu Ekonomi Persada Bunda Pekanbaru \\ J1. Diponegoro No.42 Pekanbaru \\ Email: mutiaulf@gmail.com
}

\begin{abstract}
Times changes and so do people. As times goes by, the working lifestyle of the society change rapidly. Nowadays, the society tends to prefer work independently, and work outside rather than at their own workplace. Not a few of them try to work in a comfortable place like cafe or public place. This kind of work activity on in the public sphere becoming more and more popular habits right now. Doing meeting in cafe seemed to be a habits. Some of them said that working in public sphere helps them a lots in term of popping up the creative idea. The relaxed and cozy atmosphere makes public space as an alternative meeting point. However, not all cafe or eating place were comfortable enough to work. What about the disturbance caused to others who enjoy the place as its functions? In reaction to the new working lifestyle order, new form of work emerge in various countries, name coworking space. This paper tries to figure out the ability of Coworking Space Business Model Creation in Pekanbaru
\end{abstract}

Keywords: Business Model, Coworking Space, Creative Industry, Business Management, Business Strategy

Berkembangnya zaman mengubah gaya hidup masyarakat. Mereka cenderung lebih senang bekerja independen dan bekerja di luar daripada berada di tempat kerja sendiri. Tidak sedikit yang mencoba mencari tempat seperti Kafe atau tempat makan lain yang nyaman untuk melakukan pekerjaannya atau sekedar berdiskusi. Pemandangan aktifitas kerja di ruang publik semacam ini sudah semakin menjamur.

Hasil survey dari Euromonitor (2010), hampir 98\% penduduk Indonesia yang mengunjungi kafe dan tempat makan lainnya yang sejenis menjadikan kafe sebagai tempat untuk pertemuan bisnis.

Sebuah riset "Telecommuting Citizens in 24 Countries Assess Working Remotely for a Total Global Perspective" oleh IPSOS (2011), mengemukakan bahwa Indonesia merupakan negara kedua terbesar di Asia Pasifik setelah India dengan persentase jumlah pekerja $34 \%$ yang melakukan aktivitas kerja di luar kantor baik untuk bekerja, pertemuan bisnis maupun diskusi. Hal ini terjadi justru karena perubahan pola hidup manusia yang cenderung tidak bekerja ketika di kantor karena berbagai macam alasan. Mulai dari banyaknya gangguan macam obrolan dengan kawan, ajakan meeting, e- mail dan yang lainnya. Sehingga, karena situasi kantor telalu formal, sering kali justru mematikan unsur kreativitas. Morse (2007) mengemukakan hal yang sama juga terjadi bagi para freelancer yang memilih bekerja di rumah, karena terlalu banyak gangguan terjadi.

Meeting di kafe seolah sudah menjadi kebiasaan. Banyak yang beralasan ruang publik selain kantor cenderung lebih dapat melahirkan ide-ide kreatif. Nuansa yang santai dan tidak kaku menjadikan ruang publik sebagai alternatif meeting point. Namun, pada kenyataannya tidak banyak kafe dan tempat makan yang nyaman untuk bekerja. Seperti dikutip dalam situs Gaya Hidup Tabloid Bintang (2012), studi mengenai efektifitas kerja berdasarkan tingkat kegaduhan di lokasi kerja oleh University of British Columbia menyimpulkan bahwa suasana ruangan yang tidak terlalu bising dapat mengurangi kerumitan dan meningkatkan kreativitas karena mampu merangsang otak untuk berpikir secara abstrak. Hal inilah yang menyebabkan semakin banyak 
orang yang bekerja di ruang publik. Hal yang sama juga dikemukan oleh Friedersdorf (2011) dalam artikelnya berjudul "Working Best at Coffee Shop". Sebaliknya, saat kondisi ruangan cukup berisik, proses penyerapan informasi pada tiap individu cenderung menurun, begitu pula halnya dengan kreatifitas.

Menurut Morse (2007) para individu tersebut mencoba peruntungan untuk bekerja dan berusaha seorang diri dengan modal pengalaman serta jaringan sosial. Para freelancer dan start-up business cenderung memilih rumah sendiri sebagai tempat bekerja. Namun, kondisi tersebut seolah membentuk mereka menjadi terisolasi tanpa memiliki jaringan yang berkembang. Beberapa artikel internasional seperti Freelance Apple (2010) dan Yahoo Voice (2007) juga menyebutkan, mereka yang bekerja di rumah sering kali butuh untuk bertemu orang lain untuk mendapatkan antusiasme. Hal inilah yang menjadi alasan kenapa semakin banyak orang bekerja di ruang publik. Masalahnya kemudian, tempat yang didatangi tersebut tidak diperuntukan untuk ruang kerja.

Sejalan dengan Program Ekonomi era Jokowi yang menggiatkan ekonomi kreatif untuk kedepannya sebagai tulang punggung dan pilar perekonomian Indonesia. Ekonomi Kreatif dipercaya sebagai kekuatan baru yang potensial untuk menjadi pusat pertumbuhan ekonomi nasional. Perkembangan jumlah freelancer dan perusahaan start-up di Indonesia dari tahun ke tahun pun meningkat, memunculkan gaya bekerja yang baru dimana gaya bekerja ini memiliki karakteristik yang lebih bebas, fleksibel dan mandiri, bahkan permasalahan yang muncul pun berbeda dari model kerja pada umumnya.

Masalah utama yang menjadi kendala bagi para pekerja lepas dan wirausaha muda ini adalah belum memiliki kantor tetap karena adanya keterbatasan modal. Sebagai reaksi dari gaya kerja baru nan dinamis tersebut, sedikit banyak mulai bermunculan bentuk bentuk baru tempat bekerja di berbagai negara di dunia, yang popular dikenal dengan coworking space.

Dari fakta di lapangan penulis melihat peluang yang timbul karena terjadinya perubahan gaya hidup masyarakat yang menyebabkan para pekerja lebih memilih bekerja di luar kantor daripada bekerja di dalam kantor. Masalah mulai timbul saat mereka merasa kurang nyaman dengan ruang publik karena tidak hanya digunakan oleh para pekerja, namun banyak pengunjung lain yang datang bukan untuk bekerja, sehingga menjadi sangat ramai. Selain itu, fasilitas yang dibutuhkan untuk bekerja seperti internet, fax, dan lain sebagainya juga tidak tersedia pada kafe, kedai kopi, atau restoran.

Melihat fenomena di atas, maka penulis ingin mengetahui apakah model bisnis Coworking Space yang sudah berkembang pesat di luar negeri sesuai dengan kebutuhan dan permintaan pasar di Kota Pekanbaru, dan persepsi dari Masyarakat Pekanbaru mengenai coworking space itu sendiri.

\section{METODE}

Pendekatan yang digunakan adalah deskriptif kualitatif, penelitian ini mencoba untuk menganalisa konsep model bisnis coworking space melalui persepsi masyarakat Pekanbaru dengan menggunakan analisis SWOT, Porter's 5 Forces, BMC, dan 4 Action Framework

\section{HASIL}

Preliminary Survey ditujukan kepada 200 orang yang didistribusikan melalui survey elektronik diadakan untuk mengetahui lebih dalam perilaku bekerja di ruang publik. 50 orang responden mengaku tidak terbiasa dengan perilaku kerja di ruang Publik, bahkan tidak pernah melakukannya karena memang sebagian besar merupakan Aparatur Sipil Negara. Di lain pihak sebanyak 150 orang mengaku pernah dan sering memanfaatkan ruang publik sebagai tempat bekerja.

Berdasarkan hasil tersebut, $87,80 \%$

p.ISSN: $2407-800 X \quad$ e.ISSN: 2541-4356 
dari qualified responden sudah menjadikan ruang publik seperti kafe dan kedai kopi sebagai tempat bekerja, rapat atau sekedar berdiskusi. Berdasarkan prelimary survey yang telah dilakukan, peneliti merampingkan jumlah responden sebanyak 150 orang. Yakni responden yang mewakili mahasiswa, pekerja lepas, karyawan maupun pengusaha yang berumur antara 18-44 tahun yang berdomisili di Pekanbaru mengaku pernah dan sering memanfaatkan ruang publik sebagai tempat bekerja.

Berdasarkan online survey (Surveymonkey.com) tahap kedua pada 5 Feb - 5 Juni 2017 terhadap target responden sebanyak 150 orang, diperoleh gambaran umum karakteristik responden penelitian yakni sebagai berikut:

1. Pendidikan. Dari $72 \%$ lulusan S1, $24 \%$ pada tingkat $\mathrm{S} 2$ atau lebih tinggi, dan $4 \%$ lainnya merupakan lulusan akedemisi atau sekolah kejuruan setingkat D1-D3.

2. Pekerjaan. 51,22\% karyawan, $17,07 \%$ Wiraswasta, $14,63 \%$ mahasiswa (S1, S2 atau lebih tinggi), $14,63 \%$ pekerja lepas dan 2,44\% Profesional bekerja Sendiri.

3. Pemilihan Tempat Kerja. Sebanyak $87.80 \%$ dari responden memang lebih memilih untuk menggunakan ruang publik seperti kafe dan kedai kopi sebagai tempat bekerja dan diskusi ketimbang kantor ataupun kampus. 40\% dari responden memanfaatkan ruang publik seperti kafe dan kedai kopi tersebut sebanyak dua sampai tiga kali dalam satu minggu sebagai tempat bekerja dan diskusi. 60\% responden menjadikan kedai kopi sebagai ruang publik favorit untuk tempat bekerja dan diskusi.

4. Alasan Bekerja di Luar Kantor. Sebanyak $56,67 \%$ mengatakan faktor suasana yang lebih relaks dan tidak kaku, lokasi strategis untuk meeting point yang tidak membosankan, lebih fleksibel untuk berpindah- pindah menjadi alasan utama pemanfaatan ruang publik tersebut. Sedangkan, 43,3\% lainnya mengatakan bahwa tempat kerja yang ada saat ini tidak ideal dan minimnya fasilitas kantor yang terintegrasi dengan teknologi. Sehingga, responden lebih memilih ruang publik karena menyediakan one stop service berupa tempat duduk, fasilitas internet, sumber listrik serta makanan dan minuman.

Berdasarkan hasil pengumpulan data melalui kuisioner pada tahap kedua, diperoleh gambaran lima bidang yang banyak di geluti di Industri Kreatif yakni $31.71 \%$ responden bekerja dalam sektor design, disusul $24.39 \%$ di sektor media (Televisi, Radio, Majalah, Koran, Digital), $21.95 \%$ di bidang Perfilman, Video dan Fotografi, serta $17.07 \%$ masing-masing di bidang Fashion dan Music. Mayoritas dari para pekerja tersebut berada dalam grup usia 20-29 tahun (92.68\%).

Dari $87,80 \%$ responden termasuk tipe orang yang memilih ruang publik sebagai tempat bekerja dan berdiskusi ketimbang kantor, rumah ataupun kampus. $60 \%$ responden menjadikan kedai kopi sebagai ruang publik favorit untuk tempat bekerja dan berdiskusi, $40 \%$ memilih mall dan $10 \%$ lainnya memilih kafe. $40 \%$ dari responden memanfaatkan ruang publik (café dan coffee shop dan sejenisnya) dengan intenstitas 2-3 kali dalam seminggu sebagai tempat bekerja, berdiskusi bahkan meeting.

\section{PEMBAHASAN}

Untuk mendapatkan jawaban mengenai persepsi masyarakat Pekanbaru mengenai model bisnis coworking space, penulis mencoba menuangkan konsep coworking space dalam kuisioner dengan visualiasi design. Untuk memberikan gambaran bagi responden bahwa Ide di balik konsep coworking space tidak terlepas dari menggabungkan kenyamanan bekerja di rumah, fasilitas yang lengkap seperti di kantor, dan suasana kafe sebagai ruang kerja dan diskusi, namun juga memberikan peluang untuk berinteraksi, berkolaborasi, serta membangun bisnis sebagai partner. Model bisnis Coworking Space sebagai bisnis penyewaan ruang yang menawarkan

p.ISSN: $2407-800 X \quad$ e.ISSN: 2541-4356 
suasana nyaman dan menyenangkan dengan desain yang modern. Tempat yang berkonsep seperti layaknya ruang publik yang menyediakan alternatif tempat pengganti bagi orang-orang yang membutuhkan tempat unik selain ruang publik untuk dijadikan tempat kerja atau diskusi. Coworking Space juga memberikan keuntungan lain yaitu kolaborasi, networking, dan partnering kepada para pekerja lepas dan start-up business dalam pengembangan karir mereka kedepannya.

$70,58 \%$ responden mengaku tertarik dengan konsep creative coworking space yang ditawarkan dengan alasan fasilitas yang ada dalam konsep sangat menunjang untuk kerja yang tidak ada di kedai kopi, tetapi dengan suasana yang tidak seperti tempat kerja atau diskusi pada umumnya. 82,36\% responden setuju bahwa konsep yang ditawarkan sangat unik dan berbeda dibandingkan dengan ruang publik seperti kafe dan kedai kopi yang biasa mereka manfaatkan untuk bekerja, berdiskusi, dan rapat selain di kantor mereka sendiri.

Points-of-Parity (POP) atau poin yang patut dimiliki oleh Coworking Space adalah ruang kerja dan rapat pada lokasi strategis atau one stop shopping, online booking service, perpusatakaan mini, personal assistant (upon request), fasilitas standar kantor (mesin print, fax, fotokopi, serta proyektor), virtual office, alat tulis atau stationery, unlimited broadband internet service, sumber listrik, dedicated toilet khusus pengunjung Coworking Space.

Points-of-Difference (POD) yang membedakan coworking space dengan para kompetitor secara langsung dan tidak langsung adalah coworking space mampu menawarkan kesempatan partnering bagi para freelance dan start-up bisnis dengan memfasilitasi kebutuhan mereka untuk membangun bisnisnya. Interaksi, kolaborasi, serta networking juga menjadi faktor yang membedakan dan sulit diambil dari Coworking Space dengan penyedia jasa dan produk serupa.

Keunikan yang dimiliki coworking space dijabarkan pada Points-of- Difference diperkirakan akan memberikan pengalaman tersendiri bagi para pengunjung yang telah menggunakan fasilitas dari Coworking Space. Tentu saja, poin sebagai pelopor akan menjadi keunggulan tersendiri yang akan menjadikan Coworking Space sebagai brand dan penyedia fasilitas terpercaya.

Penulis mencoba menggunakan

Four Action Framework Strategy untuk membantu mengidentifikasi elemen mana yang harus di hilangkan, ditingkatkan, dikurangi, dan di perbaharui dari 9 Block Business Model Canvas (BMC) milik pesaing. Dengan menggunakan strategi ini, penulis berharap untuk menyusun rencana bisnis yang lebih terstruktur.

Framework atau kerangka kerja ini diambil dari sebuah strategi yaitu Blue Ocean Strategy (Osterwalder \& Pigneur, 2010, p.227) yang bertujuan untuk menghilangkan jarak yang ada antara differentiation and low cost strategy. Four Action Framework berisi empat faktor yaitu Reduce, Raise, Eliminate, dan Create yang dianalisis dari kompetitor Coworking Space yaitu kafe dan kedai kopi dan serviced office di Pekanbaru.

1. Reduce beberapa faktor yang sebaiknya dikurangi antara lain adalah mengurangi jumlah meja dan kursi yang tersedia atau membatasi jumlah pengunjung, karena bila terlalu banyak dapat mengurangi kenyamanan pelanggan karena terlalu ramai.

2. Eliminate. Fasilitas penjualan makan dan minuman, karena nantinya akan terlihat sama seperti kafe. Customer diperbolehkan untuk membawa makanan dan minuman dari luar.

3. Raise Kafe dan kedai kopi memiliki beberapa kekurangan yang perlu diperbaiki, seperti misalnya meja yang digunakan terlalu kecil dan terlalu dekatnya jarak antara para pelanggan, sehingga menyebabkan para pelanggan menjadi kurang nyaman dalam melakukan kegiatan mereka. Kurangnya fasilitas seperti internet dengan kualitas baik, dan stop kontak untuk mengisi

p.ISSN: 2407-800X e.ISSN: 2541-4356 
ulang elektronik menyebabkan para pelanggan menjadi kesulitan melakukan pekerjaan mereka.

4. Create. Value Proposition: Coworking Space lebih ditujukan untuk para pekerja di industri kreatif, oleh karena itu perlu memberikan suasana kreatif untuk para pengunjung melalui desain interior yang menarik dengan memadukan kenyamanan rumah, fasilitas kantor dan suasana urban dalam kafe sekaligus. Ditambah pula dengan peluang yang akan terjadi melalui proses interaksi, kolaborasi serta jaringan yang menciptakan sinergi dalam proyek yang dikerjakan. Coworking Space juga memberikan peluang partnership bagi para pengunjung yang ingin membangun bisnisnya dengan memiliki dasar atau platform dalam creative coworking space yang memberikan pemberdayaan serta fasilitas agar bisnis yang direncanakan mudah dikenali oleh masyarakat.

\section{SIMPULAN}

Hampir $75 \%$ responden mengaku masih asing dengan konsep coworking space, namun $70,58 \%$ responden mengaku tertarik dengan konsep yang ditawarkan oleh coworking space dengan alasan fasilitas yang ada dalam konsep sangat menunjang untuk kerja yang tidak mereka dapatkan di ruang publik lainnya dengan suasana yang unuk dan berbeda dibandingkan kafe dan kedai kopi yang biasa mereka manfaatkan untuk berdiskusi, bekerja dan meeting selain di kantor mereka sendiri. Adanya peluang yang timbul karena terjadinya perubahan gaya hidup masyarakat yang menyebabkan para pekerja lebih memilih bekerja di luar kantor daripada bekerja di dalam kantor, namun ruang publik yang tersedia tidak mampu menjawab kebutuhan akan kenyamanan dan fasilitas kantor yang dibutuhkan

Mahalnya harga penyewaan tempat untuk bekerja bagi para pengusaha muda maupun para freelancer, menjadi peluang konsep model bisnis coworking space untuk menjawab kebutuhan mereka akan tempat yang nyaman untuk bekerja dengan harga terjangkau.

Lebih lanjut model bisnis ini, dikhususkan untuk menjawab kebutuhan para pekerja industri kreatif baik start-up maupun freelancer, karena berdasarkan data dan preliminary survey yang telah penulis lakukan pekerja di Industri kreatif lah yang cenderung bekerja di ruang publik, dan khusus untuk daerah Pekanbaru terdapat kurang lebih 1.000 orang start-up muda yang sebagian besar memanfaatkan rumah dan ruang publik seperti kafe dan kedai kopi sebagai ruang bekerja maupun meeting point dikarenakan kendala biaya penyewaan kantor.

Berdasarkan survei yang telah dilakukan, penulis menemukan bahwa terdapat kebutuhan pasar yang cukup signifikan di mana terdapat $87.8 \%$ responden yang menyatakan tertarik menggunakan fasilitas publik untuk bekerja atau berdiskusi dan $40 \%$ diantaranya menggunakan tempat tersebut sebanyak $2-$ 3 kali seminggu. Adapun analisa yang mendukung bahwa model bisnis coworking space ini layak untuk dijalankan di Pekanbaru yakni analisa eksternal menunjukan bahwa daya tawar pembeli masih tergolong rendah, sedangkan daya tawar penjual tergolong tinggi. Selain itu, pengganti dari coworking space dan persaingan dari kompetitor masih tergolong moderate. Dari penjelasan tersebut dapat dikatakan bahwa bisnis coworking space ini memiliki peluang yang baik untuk dijalankan walaupun ancaman munculnya pendatang baru tergolong mudah.

\section{DAFTAR RUJUKAN}

Adystiani, R. Y. (2012). Kerja di Cafe Lebih Efektif daripada di Kantor. Retrieved April 10, 2017, from Tabloid Bintang: http:// www.tabloidbintang.com/gayahidup/ psikologi/59579-kerja-dicafe-lebih-efektif- daripada-dikantor.html 
Armour, S. (2011). Generation Y: They've Arrived at Work with a New Attitude. USA Today.

Badan Pusat Statistik Pekanbaru. (2017). Statistik Data 2016: Ketenagakerjaan. Pekanbaru:BPS.

Chen, Y. C. dan Lin, S. (2013). Applying Importance-Performance Analysis for Improving Internal Marketing of Hospital Management in Taiwan. International Business Research. Vol. 6, No. 4; 2013

Coworking: Find Coworking Spaces and Meeting Rooms. (2010). Retrieved Mei 11, 2017, from Deskwanted.com: https:// www.deskwanted.com/about/howdo-i-start- a- coworking-space.html

Cushman, J. C., \& Wakefield, B. (2012, December). Office Space Across the World 2013. p.20.

Damayanti, L. (2006). Tugas Akhir: Coffee Center. Bandung: Desain Interior FSRD ITB.

Departemen Perdagangan Republik Indonesia. (2008). Pengembangan Ekonomi Kreatif Indonesia 2025. Jakarta: Departemen Perdagangan Republik Indonesia

Dewanto, F. A. (2007). Konsep Pelayanan One Stop Shopping. Retrieved April 30, 2017 from Journal Manajemen Praktis:http://www.managementfile. com/journal.php?sub=journal\&awal $=80 \&$ page $=$ services $\&$ id $=24$

Euromonitor. (2010). Indonesia - The Food Service Industry. Canada: International Market Bureau.

Ebert, Ronald J. and Griffin, Ricky W. (2015). Business Essentials. (10th ed). Essex, England: Pearson Education Limited
Foertsch, C. (2011). Is There a Life Cycle for Coworking Spaces? Retrieved Mei 1, 2017, from Deskmag: www.deskmag.com/en/is-there-alife-cycle-for-coworking-spaces189

Foertsch, C. (2011). The Cultural Background of Coworking. Retrieved April 27, 2017, from DeskMag: www.deskmag.com/en/what-iscoworking-about-the-changinglabor-market-208

Freelance Apple. (2010). The Advantages and Disadvantages of Working From Home. Retrieved April 28, 2017, from http://www.freelanceapple.com/the -advantages-and-disadvantages-ofworking-from-home/

Friedersdorf, C. (2011). Working Best at Kedai Kopi. Retrieved April 29, 2017, from The Atlantic: http://www.theatlantic.com/busine ss/archive/2011/04/working-bestat-coffeeshops/237372/

Harian Aktual. November 2012. "2014, Pemerintah Targetkan Jumlah Pengusaha 2,5\%'. Akses 27 Maret 2017.

http://www.aktual.co/ekonomi/191 4032014- pemerintah- targetkanjumlah-pengusaha-25-

Indrawati. (2015). Metode Penelitian Manajemen dan Bisnis Konvergensi Teknologi Komunikasi dan Informasi. Bandung: PT. Refika Aditama

IPSOS. (2011). Telecommuting - Citizens in 24 Countries Assess Working Remotely for a Total Global Perspective. Paris, France: IPSOS. 
Kementrian Koordinator Bidang Perekonomian. (2015). Ekonomi Berbasis Kreativitas dan Inovasi sebagai Kekuatan Baru Ekonomi Indonesia. [Online]. https:// www.ekon.go.id/berita/view/ekono mi- berbasis-kreativitas.1659.html. Akses 5 Desember 2016

Kurtz, D. L. (2008). Principles of Contemporary Marketing. SouthWestern Cengage Learning.

Latief, M. (2013, Februari 22). Harga Sewa Kantor di Jakarta Naik. Retrieved April 5, 2017, from Kompas.com: http://

nasional.kompas.com/read/2013/02/ 22/13512695/Wah.Harga.Sewa.Kant or.di.Jakarta.Naik

Matos, K., \& Galinsky, E. (2011). Work Place Flexibility in US: A Status Report. Society for Human Resources Management.

Morse, J. (2007). The Advantages and Disadvantages of Working from Home. Retrieved April 30, 2017, from Yahoo! Voice: http://voices.yahoo.com/theadvantages- disadvantagesworking-home-151728.html

Osterwalder, A., \& Pigneur, Y. (2010). Business Model Generation. USA: John Wiley and Sons.

Osterwalder, Alexander. dan Pigneur, Yves. (2014). Business Model Generation. Jakarta: PT. Elex Media Komputindo

Pangestu, M. E. (2008). Pengembangan Ekonomi Kreatif Indonesia 2025: HASIL KONVENSI PENGEMBANGAN EKONOMI KREATIF 2009-2015. Jakarta: Departemen Perdagangan Republik Indonesia.
Porter, Michael E. 2008. The Five Competitive Forces that Shape Strategy. Harvard Business Review.

Sekaran, Uma. (2006). Research Methods for Business, Metode Penelitian untuk Bisnis. Jakarta: Salemba Empat

Tim PPM Manajemen. (2012). Business Model Canvas Penerapan di Indonesia. Jakarta: Penerbit PPM

TribunNews.com. (2013). Industri Kreatif Jadi Pilihan Pengusaha Muda. Retrieved April 28, 2017, from http://www.tribunnews.com/2013/ 04/26/industri- kreatif-jadi-pilihanpengusaha-muda

VivaNews.com, November 2012. Industri Kreatif Serap 8\% Tenaga Kerja Indonesia. Akses 29 Maret 2017. http://bisnis.news.viva.co.id/news/r ead/369272-industri-kreatif-serap8-persen-tenaga-kerja- indonesia

Warta Ekonomi, 2013. "Cushman \& Wakefield: Pertumbuhan Harga Sewa Kantor di Jakarta Paling Tinggi di Asia Pasifik" Akses 15 Maret 2017. http://wartaekonomi.co.id/berita80 29/cushman--wakefieldpertumbuhan-harga- sewa-kantordi-jakarta-paling-tinggi-di-asia pasifik.html

Zikmund, William G. \& Babin, Barry J. (2013). Essentials of Marketing Research, (5th International Edition). Canada: South Western, Cengage Learning. 